\title{
The Historical Development of Children's Literature in Turkey
}

\author{
Beytullah Karagöz \\ Faculty of Education, Gaziosmanpaşa University, Turkey
}

Copyright $\bigcirc 2018$ by authors, all rights reserved. Authors agree that this article remains permanently open access under the terms of the Creative Commons Attribution License 4.0 International License

\begin{abstract}
This study aims to examine the historical development of children's literature in Turkey. In this context, developments and changes in the field of children's literature have been evaluated according to the chronological approach. In doing so, the authors and their works, important turning points of Turkish child literature history, were evaluated. The research is in the literature survey model and the status is determined in the study. It has been commonly known that there are four basic approaches in the history of Turkish children's literature. The first three groups of these schools evaluated the children's literature within the context of giving advice, being instructive, and lecturing. In the understanding that develops after the 1980's, children's literature is considered as an important field of art in terms of improving the child's emotional world, and improving his thinking and inquiry skills.
\end{abstract}

Keywords Children's Literature, Turkish Children's Literature, Historical Development Process

\section{Introduction}

\section{The Historical Development Process of Children's Literature in Turkey}

"Children's literature demands delicate workmanship. It is a damasked gem on a ring. The ring is a rough gold. However, the gem which demands value craftsmanship, knowledge, caution, master cutting, damascene, nailing and love- is a diamond stone. Cutting a diamond is a difficult work; it needs experience, knowledge and craftsmanship. Crafting is also another technicality. Therefore, children's literature is jewelry; it is such a literature field that separates beauty and ugliness and regardless of its charming gloss, keeps beauty inside."

The common view of many researchers studying children's literature is that the first steps of children's literature field in Turkey began in Tanzimat reform era. It can be said that this idea could be a right approach from the point of similitude and orientation to contemporary literal forms in the West. Besides, in the pre-Islamic era, which can be referred as classical era, children's presence attracts attention in the works belonging to oral and written tradition, as well. The researchers' opinions on the beginning date of children's literature are not false but incomplete. Moreover, as in the other societies, children have a valuable and important place in Turkish society, as well. For this reason, Turkish family and mentality can be seen clearly in archaic cultural sources which handle 'children and children problem' in chronological flow.

\section{Materials and Methods}

Literature review model is used in this research. The results are examined by using the information compiled by means of descriptive analysis. As using status determination in the survey the universe and the sample have not been selected. During the data collection phase, the information obtained about the subject is processed in the data recording forms. The information processed in the forms has been arranged in accordance with the purpose of the research.

\section{Results}

Before the acceptance of Islam, oral tradition is dominant in our literature. It is possible to see epic, tale, lullaby, legend, folk story, fable and similar types of oral literature which carry the trace of nomadic culture. In nomadic era before Islam, The Epic Oghuz Khan is the most well-known work. The struggles with Turkish people for sacred values like religion, independence and land are narrated in this epic. Thus, the life of heroes in the epic is not described in order like childhood, youth and elderliness. The fore stated stages of life are not mentioned since they 
are the preparation stages for adulthood which is considered as the main stage of life. For instance, Oghuz who is put to the breast only once, grows in forty days and becomes 'the figure of healthy man' prevailing on Turkish culture proves this idea.

Another prominent work about children and the education of children is "Dede Korkut Stories". Fuat Koprulu states that "If you weigh up all Turkish literature with Dede Korkut, Dede Korkut outweighs anyway." The work praised by Koprulu gives information about the structure of family in Turkish society, their social and cultural life. In the background of Dede Korkut, the presence of child for the family gains importance. Within this context, Bayındır Khan in the story of "The Son of Khan Bogac Khan" says "Allah damned the people that haven't got any daughter/son, so you should know that we also damn. As stated in the foretold epic, having a child is a privileged situation spiritually and socially. In the same epic, Dirse Khan, who cannot have a daughter or son, is punished by being settled in a black pavilion, given a black mat and brought black sheep 'Yahsin'. In the work, a special importance is given to the education of children. In this respect, it is remarkable that there is not any sex discrimination: “A girl doesn't get advice unless she catches her mother's attitudes; a boy doesn't set the table unless he catches his father's behaviors." However, the son is considered more important to keep the family name alive. "Son is the one raised for the place of father; he is like one of his eyes." The tradition of "name giving", which is still important to Turkish culture today, takes place in 'Dede Korkut Stories.' For Turkish ancestors, the boys were supposed to show heroic deed by overcoming the difficulties, and do some beneficial things for public to have a name. He couldn't have name unless he succeeded in these conditions. Until he had a right to have a name, he was called "nameless". In the story Bamsi Beyrek [The Son of Kam Pure], Bamsi Beyrek's name giving ceremony is stated as "Dede Korkut came, gave a name to the boy, May Allah give an opportunity to your son /You fondle your son saying Bamsi/ So his name be Bamsi Beyrek with a gray studhorse / I gave his name, may Allah gives his age It is possible to sum up and conceptualize all these extracts from the words of Türkdoğan: "the model developed around the social system represents not only the beliefs and ideologies which can be called as value orientation, but also social structure, role, status and norms".

Kutadgu Bilig written by Yusuf Has Hacib (1017-1077) between 1069 and 1970 is a didactic work written in verse [6645 couplets]. The advices on the education of the young people take place in the work. The importance of raising a child and the responsibilities for having a child are told. The child begins to shape his/her semantic world by imitating the behaviors of his/her parents. In this context, Yusuf Has Hacib states that; "Even if royal person dies, his ancestry is enough / What you plant, it grows / The nature of son resembles his ancestors". The work contains some promptings that can inspire value and behavior for the children education. To give an example, -"Wherever you go, be good. Do not pay attention to the ancestry and nobility, look for the goodness inside of you/ A man should be good/ good people find happiness everywhere/ Goodness is good at everywhere/ Do good things and good things will happen to you / Make goodness, do not be bad"

EmeerUnsuru'l Maali Keykavus, wrote 'Kabusname' in 1082 to give advice to his son. "Kabusname is a guide book related to nourishment, illnesses, play and rest of children" .Kabusname is translated from Persian language by Mercumek Ahmet, and presented to Sultan Murad the $2^{\text {nd }}$. The work, which is praised by the Sultan, was studied as a course book at educational institutions in Ottoman Empire. This work presents some tip about the education paradigm of the era. It is determined that severity and punishment were the main instruments of children education in Kabusname. Yahya Akyuz, in his work 'The History of Turkish Education' quotes the concept of the education and discipline instruments in Kabusname: "If teacher beats your child, do not feel sorrow for it. Children learn knowledge, art, and morality by beating. The fear of beating and scolding is important educational instruments. Children don't want to learn anything willingly".

According to Gazzali (1058-1111), the wise and erudite scholar, it is necessary for children to take religious education and discipline for the life and afterlife. In this respect, he writes the pamphlet called Eyyuhel Veled (Oh, Son!). In the pamphlet, the meaning of the worship and obedience to Allah, necessity of being liable to Prophet Mohammed and the necessity to live as to the attitudes and behaviors according to Allah's order and prohibitions are emphasized. Gazzali associates the education of children to "the embroidery on a stone." This axis would be cod as 'Tabula Rasa' by John Lock who is the pioneer philosopher of social enlightenment in the West. Gazzali hopes that the child reaches the identity of ideal person -the idealistic aim- at the end of the heavy, tedious and tiring educational period. Thus, he states that family has an important duty on the education and discipline of children as they are the first teacher of the child. "The child is like clean soil on which you spread to grow. If you plant goodness seed, goodness grows, if you plant badness seed, badness grows. If goodness seeds are planted, s/he will reach the happiness of life and afterlife"

Education and discipline of children are the topics handled in Divan literature. With this aim at the works written in $17^{\text {th }}$ and $18^{\text {th }}$ century, two works are very important; Hayriyye and Lutfiyye. Hayriyye is an advice book written by poet Nabi (1642-1712) to transfer his knowledge of life experience to his son Hayrullah to gain happiness in life and afterlife. Nabi begins his work by presenting himself to his son. Under 36 titles, he emphasizes the conditions of Islam and the things gained by carrying out these conditions to the character and moral of people. Besides religious knowledge, he doesn't neglect 
to tell about the personal characteristics essential for the world. "Ol ganîtabu tevâzûpişe / Sal gülistânı felâha rişe" (The person who is well behaved and modest is not deprived of true friends); Handerûluk eseri rahmetdür / Türşrûluk sebebi nefretdür" (Geniality makes one loved and respected/ grouchiness makes one hated).

Lutfiyye (1791) is written by Sunbulzade Vehbi to advise his son. It is known that it was written as a reply in kind to Nabi's Hayriyye. In this book, Sunbulzade Vehbi not only gives information about the things he should and shouldn't do in life. Just as Hayriyye, in the book in which it is told the importance of the utility of working for the life and after life, it is emphasized that the necessity of not to abandon world life besides the utility concerning about Islamic science.

While in the works up to Hayriyye and Lutfiyye, the advices are given to the parents that would raise the children; this book addresses directly the children. Both books are quite remarkable according to their era. Although the works are beyond their era in terms of method, "they do not have the quality of being read and understood by children in terms of their language and content neither in the era they were written nor after". With this context, these verses are suggestive enough to give idea about the linguistic structure of the books: "Bedzebân olma nigügüftar ol / Kavli leyyin ile bîazâr ol" (Do not be sharp-tongued, be smooth- tongued / speak mellifluously, do not snap).

In Turkey, whenever the literary works about the children are thought, the first answer has been the accumulation of the oral tradition for years. Tales, legends, myths, riddles, rhymes have fulfilled the aesthetic and fun requirements of children. In the last period of Ottoman Empire, changes occurred in the system of world politics. A powerful demand of alteration affects all layers of society and system of government. Ottoman Empire brings about structural arrangements to keep its position in the system and continues its existence. "The Rescript of Gulhane", declared in 1839, is the most important regulation among them. With this rescript, the orientation movements to western world gained acceleration. As a result of increasing contact with the west, improving knowledge of intellectual people on other countries, and returning of the intellectual people to country from abroad, the necessity of reforms in educational institutions came to exist. The understanding - objectification of children- of madrasah gives its place to a new concept, "child as a valuable being."

The writers of the era, categorized as innovation era later, "try to describe a world that hasn't existed yet, full of beauties, imaginaries, trueness, in the fresh memories that they plan to raise in the aim of their idealistic aim in their works. They haven't constituted this different world but the children would. There are so many things going wrong and the individuals that would resolve failures; the children that are the adults of tomorrow should be educated."
The educational institutions are the first places that carry out the foretold responsibilities. With this approach, the need of educational materials for the education of children in schools comes out. Thus, in Turkey the period of copyrighted and translated work begins. Nuhbetü'l-Etfal (1858) written by Dr. Rustu, born in Kayseri, is the first known work of the era. Nuhbetü'l-Etfal (1858) includes tales and fables for children. Even it is said that "it is written to give reading pleasure to children the work features as an alphabet book. With the explanation of Sariyuce "It is written with the aim of teaching children reading and writing in Turkish with easy and pedagogical methods, but not to correspond to their literary need.

In this era, periodical publications are started to be published for children. Mümeyyiz (1869) is published for children for the first time. It is the additional part of the same newspaper given every Friday. There are entertaining parts, current news, advertisement and announcements, letters, fable- tales -stories, advice parts, and encyclopedic parts in its content. After Mümeyyiz, the second child newspaper Sadakat (1875) begins its publish life. It is published every Sunday. After the $6^{\text {th }}$ volume is published, it changes its name and continues as "Etfal." Etfal continues the other publication's style with similar content. The common characteristics of journal is to shape the spiritual world of the children, to educate the children from the very young ages with the proverb "as the twig is bent, so grows the tree" rather than aesthetic pleasure. This aims to enliven the national and moral values that are about to disappear, and to help Ottoman Empire, trying to overcome problems, via literature.

Mehmet Semseddin is the first person that takes the children newspaper and magazines in an independent way. According to Okay; "It is necessary to wait Mehmet Semseddin's Arkadas journal to see the first primary examples of this type when considered as a literary work. Mehmet Semseddin is conscious of giving production of children and writing for children as a different field and concept. "His efforts in this matter begin to be seen with Arkadas journal published in 1877. The tales in the journal is different from the others in its point of view on children. "I will say the things, I will say like I am talking. Until, you can understand what you read by yourself. Arkadas is not published after its $13^{\text {th }}$ volume. Mehmet Semseddin insists on publishing journals. He publishes Cocuklara Arkadas (1882) and Cocuklara Talim (1887). In these journals, short educating short stories, writings about nature, world and similar subjects are published and can be understood easily by children.

In Tanzimat reform era, it is seen that translation activities take an important place in children literature. The developments starting in the first stage of the era of translations and continue until the second "constitutional monarchy period (1908). In this era like Sinasi, Ziya Pasa important writers gave literary classics. Tercüme-I Manzume by Sinasi was published in 1859. In this book the 
translation of "Story of Donkey and Fox by La Fontaine" takes place. Besides this translation, in Muntehabat-I Eş'ar (1862), there are 4 fables written by himself. Ziya Pasa translates Emile, written by Jean Jacques Rousseau about child and child education, in 1872.

Ahmet Mithat Efendi carried out important studies regarding increasing the child education, knowledge and good manner. This is because Ahmet Mithat attributes a mission to education which can change the society and solve the problems of society. "Expansion of education through the country, increasing number of literate people and the students graduated from the schools opened lately, also set the consciousness of western science and education" will enable education opportunities to the society and increase the level of welfare. In connection with this idea, Ahmet Mithat utilized the literate works, newspapers as an educational instrument with the intent of reaching to these aims. His work such as Hace-1 Evvel (1870), Kıssadan Hisse (1871) and Tercumanı Hakikat were written to enlighten the society.

After Tanzimat reform era, the movements that away idea originating from Western were discussed intensely and accepted in Turkey. With the effect of the movement towards freedom idea in 1876, Kanuni Esasi which restricted the rights of Sultan was prepared and Meclis-1 Mebusan, the delegates of public, was opened. Because of wars and unsteady political structure, this period didn't continue long. In 23 July 1908, with the result of coup done by "Unionize soldiers", constitutional monarchy was declared again. The pioneers of movement saw themselves as a commission enlightening the society because of their elitist point of view. In this context, they primarily focus on the educational issue. They applied the transformative power of education to transform the society. According to their opinion, education was the unique instrument to eliminate the ignorance of public and educate them.

In order to accomplish this ideal, Dârülmuallimîn opened in 1848 was given importance. It was aimed to educate constitutionalist intellectuals/idealists. The importance of the school came from Sat1 Bey who carried out directorship duty between 1909 and 1912. Sat1 Bey strengthened the teaching staff of the school with respectable names. "Halit Ziya, Tevfik Fikret, Vasil Naum, Hamdullah Suphi, Ihsan Şerif, Siracettin, Harun Reşit, Hafiz Kemal, Ahmet Cevat, Ali Nusret, Ruşen Eşref, Fazıl Ahmet are the teachers that come to mind who worked in Âli section of Dârülmuallimîn" With the reformist-intellectual teaching staff, it was started to educate teachers that have the modern mentality the society needs. Satı Bey first of all found out the inadequacies by analyzing the education programmes. He noticed certain inadequacies of physical education, music, science, and children literature fields. There were only Tevfik Fikret's "Hep Kardeşiz" and "Küçük Asker" songs, "Ağustos Böceği ile Karınca" and "Az Tamah Çok Ziyan Verir" myths; Süleyman Nesib's one poem and Mehmet Emin's three or four poems as children literature works. Satı Bey took action to prepare education materials which students would be able to use in children literature and music fields. $\mathrm{He}$ invited the experts on their fields to eliminate these deficiencies. For this purpose, he held a conference "Siir ve Musikinin Talim ve Terbiyede Ehemniyeti" which poets and composers of the period attended in Dârülmuallimîn in 1910. He explained the importance of poem and music in education. He tried to show the effect of music on human emotions by making students read poems and sing songs because poetry and music are the initial needs for school and student. In the following days after the conference, significant number of works emerged which might be added to children's literature field. Çocuklara Şiirler is the first work by İbrahim Alaaddin which was published in 1911 with the encouragement of Satı Bey. Ali Ulvi who was encouraged to translate and publish the poems written for foreign kids by Sat1 Bey, published Çocuklarımıza Neşideler in 1912. The book doesn't consist only of translations. In the work, there were about ten French poems in nearly seventy poems. Tevfik Fikret is one of the corresponding people since he was working as a teacher at the school and because of his personal esteem for Satı Bey. In 1914, he wrote Sermin which is one of the first works of our children's literature. "In his work, there were thirty one examples related to alphabet, game and toys, nature and animal love, pity, function as the school, work as a virtue." The prominent characteristics of Şermin comes from its competent structure and the traces of child sensitivity in it

Compared with Tanzimat Period, in II Meşrutiyet Period it is seen that more qualified works has had the chance of progressing and improving in child's literature field. Writers has written suitable works for children which pay attention to children sensitivity by making use of the knowledge about children whereas it is a fact which shouldn't be ignored that informative and didactic function content in the works was protected while it was raising.

Ziya Gökalp is an important writer who made contributions to the development of children's literature in II. Meşrutiyet Period. Gökalp has a unique place in Turkish thought and literature history not only with his studies but also his pedagogical identified children's works. In education and training field, he influenced that period's methodology and politics by using data of sociology science. In order for Turkish children to have the consciousness of history with their national identity, he penned Klzll Elma (1915) which is specified as the holly aim of Turkishness, Altın Işılk (1923) in which he reinterpreted some of the Turkish folk tales in poetry and some of them in prose. In addition to this, Gökalp's Limni ve Malta Mektuplarl works which is accepted as a good representation of the letter genre in Turkish literature should be mentioned. It is seen that in the letters, writer has proposed some ideas on subjects like women, family and children. According to him, it is a necessity for a woman to be educated for family and children. "To train a child is not 
to make him give up only bad habits. It is inspiring him to good nature. Here, being in simple behaviors and love are seen as important elements". With a more specific definition, it lies at the center of giving importance of children education to make them be good people-good citizens that do good and beneficial things.

In this period, Ömer Seyfettin is another remarkable writer in children's literature. His stories, which he wrote by centering his own childhood and Turkish history, hit the turn mark of that period. Ilk Namaz, Ant, Ilk Cinayet, Kaşağl stories have autobiographic elements about his childhood period. His stories like Pembe Incili Kaftan, Forsa, Başını Vermeyen Şehit put forward main cultural values which wrap Turkish history and Turks' heroism and convey him to social member stage. The author immanent in history, even today loved by the children thanks to the National by intense precision to date can be read.

Cumhuriyet era begins with the promulgation of Turkey's management style is Republic in 1923. In this period, it is a necessity to adopt Western civilization for the newly established state. Modernization movements starting from the last days of Ottoman Empire, has maintained its presence without slowing down in order to close the current gap in the first years of the Republic. It has been exalted as a national goal to catch and exceed the Western civilization level. For this purpose, there have been some changes in alphabet, modernizing practices clothing, weighing scale and laws via modernizing practices. A formal resemblance has been provided by taking concrete and abstract cultural elements of the Western world.

The Literary Revolution which took place in November 1,1928 , has required a series of changes in the field of education and culture. When Atatürk established Nation Schools as Head Teacher, a nationwide literacy campaign started. The alphabets written between 1928 and 1935 and the supporting texts for learning to read are in the foreground in the quantitative sense. It is seen that in the Republican era, the life of a live publication has sprouted and the field of children's literature has gained momentum. Although the number of works is sufficient for quantitative plan, presented works do not have the required qualifications for quality. These works follow the aim at both meeting the needs of children's need for reading and inspiring the growing generations of strings of values of the new regime. With a concise specification, writers use their literary works as an instrument with the aim at adopting the truths in new regime because the country just got out of the Independence War. On that account, they choose to tell the events and heroes in the past with exaggeration. This situation is seen necessary to train individuals that are qualified to receive the frame of values brought by new management form because the novelties made on the perception level of the social stratification haven't been realized as expected. It's thought that authors of the period should be regarded as oppressive depending on the structure movement when the originality of historical and social contexts of transforming practice mentioned at this point.

In the years following the declaration of the Republic, it possible to locate that children perception has differences than other periods. It is constantly emphasized that children have a different value of family and regime via activities and publications intended for them. The most emphasized subject is to internalize the novelties that brought by Republic and to transfer the functions of the new management style to growing generations. For this reason, Mustafa Necati Bey, the Secretary of National Education of the period, makes it possible to create a selection of children's literature works composed of three serials. According to İbrahim Kıbris, these serials were arranged:

a "Examples of World Literature was prepared by name like Hakkı Süha one of the known authors, Ali Canip Yöntem, Hasan Ali Yücel and many domestic and foreign classical works took place in this serial such as, İlkbahar Seneleri, Naima Tarihinden Seçmeler, Epope, Sanat Muhasebeleri.

b School Plays: This serial written separately for boys and girls schools was written by Mahmut Yesari, Reşat Nuri, İbnürrefik Ahmet Nuri.

c World Children's Classics: Today, the classical works such as Arı Maya, Heidi, Kimsesiz Çocuk, which are read by children with desire, were translated in those years and also they were sold with low prices including the ones which had been translated earlier"

In this period, in addition to the studies mentioned above, it is seen that works written in the form of poetry also come forward. Poets known as "Beş Hececiler" contributed to children's literature with their poems. Enis Behiç Koryürek with his poems written with national sensibility, Halit Fahri Ozansoy with his subjective and emotional works, Faruk Nafiz Çamlıbel with his Akncı Türküleri (1938) in which he told his longing to the past, Yusuf Ziya Ortaç with his Kuş Covvltıları (1938) which carries the traces of the trails of childish sensitivity, Orhan Seyfi Orhon with his poems which was poetized in style of Peri Kızı ile Çoban Hikâyesi influenced improving of the children's poetry.

It is seen that along with "Beş Hececiler" famous poets have headed and given qualified works in children's literature. Orhan Veli translated the fables written by La Fontaine to Turkısh language and published them in 1943 with the name of La Fontaine'in Masallarl. At the same time, in the same work he quotes the suggestions made by his friend Şevket Rado "it would be a good thing to write in poetic form of Nasreddin Hoca's anecdotes". By inclining this point, he publishes seventy nine anecdotes known to belong to Nasreddin Hoca in 1949.

Şükrü Enis Regü (1922-2974) contributed to the children's literature with his poetry books BayramYeri (1947) and Elma Ağacı (1971), his compilations named Çocuklar İçin Atatürk, Memleket, Tabiat ve Aile Şiirleri 
(1958), his book named Onlar da Çocuktu (1972) in which he told the stories of famous people for kids.

Fazıl Hüsnü Dağlarca is one of the authors that wrote original and qualified works in children's literature of Republican period. One characteristic of Dağlarca is that he gives work by depending on childish sensitivity. According to Şimşek, "Dağlarca, who proves his familiarity to the subject with themes he handled in Cocuk ve Allah which he published in 1940, gives the first signs of hearing and saying particular to children." Mustafa Ruhi Şirin approves these opinions on a remarkable openness. Dağlarca, "is a turning point in orienting to children in Turkey. Since 60s, he is the first poet to orient to child subject. He hasn't told about children and childhood like TevfikFikret. He is also the first to dare to write to the children with the perspective of children".

Dağlarca's first children book is KuşAyak: Açıl Susam Açıl, which was published in 1967. Dağlarca focuses his poetry work on children's poetry between 1977 and 1981.Balina ile Mandalina (1977), Yaramaz Sözcükler (1977), Yazıları Seven Ayı (1977), Göz Masalı (1979), Şeker Yiyen Resimler (1980), Güneşi Doğduran (1981), Ilkokul 2'deki/Kanatlarda (1981) are the works of this period. Having reached an advanced competence in children's poetry, Dağlarca proved his success in this field by increasing his poems quantitatively till his death. It approves the mentioned opinion that he wrote nearly twenty children books.

Mümtaz Zeki Taşkın (1915-2009) contributed to the improvement of children's poetry with his Çocuklarımıza Resimli Şiirler (1959) book. Mümtaz Zeki has an important place in children's literature field and his books named Mavi Boncuk (1936), Adını Çocuklar Koysun (1952), Oyuncakçı Dede (1955), Çitlembik Kız (1975), İstanbul Yemişi (1980), Sampiyon Topaç (1988) are a reflection of the importance he gives to child and child's education.

When children's novel is compared to poetry, it is seen that its pace of advancement is slower. Because novel-writers of the period have just discovered the reality of children, products are not enough. Authors penned works including child heroes rather than writing children's novels. Hence children met their desire for reading with the books written for grown up people, addressing to every reader mass. Among them, Halide Edip Adivar's (1884-1964) and Yakup Kadri Karaosmanğlu's (1889-1974) works can be shown as examples. Halide Edip, who defines children as "refreshing spring", takes part in education community as teacher and inspector and has great serves in our education system with her suggestions. Halide Edip's and Yakup Kadri's stories like "Bayrağımızın Altında", "Duatepe", "Tanıdığım Çocuklardan", Kabak Çekirdekçi", "Güvercin Avı", "Ceviz" which takes place in Dağa Çıkan Kurt (1922) and Millî Savaş Hikâyeleri" (1947) can catch today's reader in the way of knowing great authors, both giving language pleasure and inspiring to national consciousness and human love with their literary and instructive side.

Among these authors, it will be appropriate to accept Abdullah Ziya Kozanoğlu (1906-1966) an important writer. By Şirin's statement, his novels like "Kızıl Tuğ (1923), Atlı Han (1924), Türk Korsanlarl (1926), Seyit Ali Reis (1927) and Gültekin (1928), which were written with Ottoman letters first and then published in Turkish, are the books which he wrote by taking consideration of young's curiosity, interests and taste . Abdullah Ziya, in his works, which are fed from historical events, aimed Turkish children to become equipped with history consciousness by balancing fiction and reality. It is possible to infer this aim at the passage through the end of his work named Klzll Tug "my aim to ensure that Turkish people trust in themselves, brag about their ancestors and see themselves successful.

Cahit Uçuk (1911-2004) is another author who writes novels by children. Uçuk is famous for his work Türk Ikizleri, published in 1937. This work was rewarded with Award of Honor in International Children's Books Union Christian Andersen Competition in 1958. It is observed that in his book named Gümüş Kanat (1962), she couldn't escape from falling into the trap of didactic quality while aiming to make children understand the universal values such as acting together, resistance to difficulties, sacrifice and family.

Since 1930s, a quantitative increase is seen in children's novel. The process starting with Mahmut Yesari's book Bağrı Yanık Ömer (1930) sustains its development with Rakım Çalapala's (1906-1995) 87 Oğuz, Huriye Öniz's (1887-1950) Köprüaltı Çocukları, İskender Fahrettin Sertelli's (1895-1945) Tahtları Deviren Çocuk.

Kemalettin Tuğcu (1902-1996), who is stated by Fatih Erdoğan as "one of the important milestones of our children's literature", spread the children's literature countrywide with his novels. Being committed to creating "ideal child" ideal which was adopted as an aim at Cumhuriyet Era children's literature, the author didn't give enough importance to literary dimension while suggesting giving lessons directly in his works. In Tuğcu's novels, there are basic human conflicts such as good/evil. Even though he is criticized for making children's world pessimistic because of excessive sentiment, "the convenience of the life which they reflected on real life", "not aims anything but to squish our lachrymal gland, exploit out pity", in the heart of every children in Turkey, has a story of Kemalettin Tuğcu. In connection with this, popularity of Kemalettin Tuğcu gains a wide dimension. Film industry couldn't be oblivious to this productive author of children's literature. Short novels named Ayșecik (1960) and Üvey Baba (1971), which depends on the literature's narrative power, were scripted and adopted to movie screen in which children stars acted.

The ends of 1960s are timing that socialist-realist view on children's literature makes itself feel thoroughly. In this period, a group of writers are of "the same mind in creating a national children's literature; preparing books based on 
our own cultural sources; bringing world's classics into Turkish with a more meticulous choice and a better translation."

In this way, writers that write much more for adults have the opportunity in presenting their mental and imaginary motivation composed of constituting a socialist-realist world under the influence of their ideological thoughts.

In this scope, Bekir Yildız (1933-1998) who subjectively reinterprets milestone events in Islamic history, the Prophet Tales, within the context of progressive- reactionary forces dualism in the society, contributes to the development of children's literature with his books, titled Arlar Ordusu (1981), Ölümsüz Kavak (1981). Afterwards there is the book titled Mahşerin Insanlarl, first edition published in 1982. There are 3 tales in this book; "Mahsserin Insanlart", "Kör Güvercin" and "Şahinler Vadisi". "Kör Güvercin" and "Sahinler Vadisi" are textbook examples of children's tales written under the influence of ideological patterns. Criticism raised commonly against Yıldız is valid for his work that he writes for children. Yakut's determination "he uses his character like puppets in order to represent his own ideas is because a writer gives a speech when he wants to give a message to his readers" helps to understand before mentioned subject. Yildiz is a writer who shows a maximum effort in telling the doctrines he believes in all his life. His work serves this purpose, as well. However, using literary works as an example to transfer one's world view is an unacceptable technical fault of the literature appealing to children.

Gülten Dayığlu (1935), one of the most important writers in Turkish children's literature, left 50th year behind in her authorship experiences that she began as a teacher. Honored guest of the 31st Istanbul Book Fair in 2012, her first book is Bahçıvanın Oğlu, published in 1963.The main work she owns her fame is Fadis (1971).The book in which a little girl's tale full of misery and sorrow is narrated is written so simple that every child can understand easily and can find something from his/her own life in it. The writer's expressions, "I am a teacher and I know children well. So, I believe that it is wrong to write our own truths to the children's book as a message", gives us information about what kind of vision she has for children's literature.

Besides some novels in which social problems are narrated, Dayığlu wrote other novels such as Dört Kardeștiler (1971), Akillı Pireler (1982), Ișın Çă̆g Çocukları (1987) in science fiction category. However, it seems that she cannot adjust well the level of didactic at times in her works Doğal Güzellikler Ülkesi Kenya'ya Yolculuk (1993), Kangurular Ülkesi Avustralya'ya Yolculuk (1994), which are attractive examples of travel writing types.

Mustafa Ruhi Şirin (1955) is a pioneer man dedicated his life to children. He thought about children and their problems of Turkey and searched for a solution. For this purpose, he established children's foundation in 1990. This foundation is a social attempt, achieved creating awareness on children's subject in Turkey. It is not wrong to say that Mustafa Ruhi Şirin has an important role in bringing children's case and rights to forefront in Turkey. Sirin, who always stands for children and their rights, makes creative and productive contributions to the development of children's literature in Turkey with his literary works. Besides his theoretical research works such as Cocuk Edebiyatı, Çocuk Edebiyatı Kültürü, Çocuk Edebiyatına Eleştirel Bir Baklş, Televizyon, Çocuk ve Aile, Çocuk Hep Çocuk, he has different kinds of works related to children such as Rüyâ Saati (poem), Aşk Olsun Çocuğum Aşk Olsun (essay), Kar Altında Bir Kelebek (tale), Mavi Rüyalar Gören Çocuk (Kaloghlan tales for primary school), Geceleri Mızıka Çalan Kedi (fable).

Cahit Zarifoğlu (1940-1987) is known for his poems and tales that he writes benefited from traditional opportunities in the fields of children's literature. Despite the fact that he later entered children's literature field, he has succeeded in giving permanent works in his short life. Zarifoğlu, writing for children after 1980, gives qualified works full of awareness against children such as Ağaçkakanlar (fable), Serçe Kuş (fable), Yürekdede ile Padişah (fable), Motorlu Kuş (fable), A $\breve{g} a c ̧$ Okul (poem), Gülücük (poem), Kuşların Dili (fable).

Fatih Erdoğan (1954) makes contributions to the field with his work in academic area and magazine publishing. He has a different place among his colleagues because he separates his work into different ages and groups according to the pedagogical principles. Erdoğan "established Mavibulut Publishing House whose main field is publishing intended for children and published the first children's magazine Kırmızı fare in 1990". He becomes the editor for children's literature research magazine, Binbir Kitap, which is the first in the field.

Speaking of Erdoğan's magazine publishing, it is to the point to examine Republic Period magazine with a broad scanning. If this is evaluated with Koçer's guidance;

"It is seen that there is an increase in the number of children's magazines after the Republic. The important ones can be put in order like that; Sevimli Местиа (1925), Gürbüz Türk Çocuğu (1926-1935), Ateş (1930), Çocuk Sesi (1932), Afacan (1934), Yavrutürk (1936), Gelincik (1936), Çocuk Gazetesi (1938), Bin Bir Roman (1939), Çocuk Romanları (1941), Çocuk Gözü (1945), Sen Çocuk (1945), Doğan Kardeş (1945-1978), Karınca (1952), Çocuk Haftası Yıllığ (1959), Milliyet Çocuk (1977-1990). Furthermore, in 1970s, Mavi Kırlangıç and Mavi Kuş, Kırmızı Bisiklet and Kırlangıç, published by Yeşilay, have an effective role in developing children's literature. Among these magazines, especially, Doğan Kardeş, published by Vedat Nedim Tör, comes to the forefront by both its giving pleasure from children and its ability of discovering children that have talent for art."

Gülçin Alpöge (1935), who has academic studies in the field of children and languages, is one of the leading names 
of contemporary children's literature with more than 25 children's books."Dedemi Özlüyorum (2004), Şıpşıp ile Tiptip (2005), Aslı Pazarl Bekliyor (2006) are among the noteworthy works of Alpöge"

Serpil Ural (1947) writes some works with "the purpose of giving information about children's language and expression in some subjects that they have difficulty in understanding". Ayr1 Evler (2011), written for children aged 6 years and over and pictured by herself is a very remarkable example. Ural reflects the influence of the divorce - the most common humanity situation in modern times - on children in the work. The experienced writer aims to keep the child away from the negative effects of the divorce by developing positive feelings and thoughts with a positive understanding. In addition, "Ural, who also makes translations from Indian books, contributed to multilingual books written for projects aimed at developing Turkish-Greek friendship"

Mevlana Idris Zengin (1966), who is still on the forefront of the poet's identity, reflects his poetry voices to his stories and tales for "catching the universal child sensitivity" Mevlana Idris declares that it is necessary to struggle to create contemporary children's literature in order to construct a permanent civilization by characterizing literature as a "sinner who neglects the child". Mevlana Idris, who achieved important achievements in children's literature at a young age, earned the first child poetry prize with his poetry book Kus Renkli Çocukluğum (1990) while he was studying at the university's final year. Mevlana Idris puts together interesting series of books titled Tuhaf Adamlar/Acayip Hayvanlar, which combines poetry with tales, and Korku Dükkânı, Hayal Dükkânı, Çınçınlı Masal Sokağı, Sufi ile Pufi, Kirpiler Şapka Giymez, Dondurmalı Matematik, Vay Canina!.., Tehlikeli Bir Kipat with both his wording full of intense, unadorned expressions in terms of formalism / legibility and that is worth reading for the contemporary child's liking. Therefore he maintains the position of being a productive representative of our childhood literature.

The development processes that started with the oral tradition of children and literature have extended to the present day with the possibilities of written tradition. The academic works in this area and the contributions to literary writers for children have led to the creation of a unique collection of children's literature.

According to Mustafa Ruhi Şirin, four authors can be mentioned in terms of periods and published books: The division of the author by focusing on historical accounts, works of children's literature and authors are enlightening on this level convincingly:

a Writers and novelists who make translations and adaptations of western poetry, and still along with heroic children,

b The didactic 'writers' that gave the first examples of works such as poems, educational stories and fairy tales that they wrote in the textbooks with the
Tanzimat and were active from the Republican period to the mid-1990s,

c Authors who have tried to write for children in spite of writing for adults,

d Turkish children's books writers of post-1980 who adopted literary and artistic understanding with child age groups and centred children and childhood with this way.

Sirin says that "the author tradition that will leave a mark on Turkish children's and youth literature has started to be formed in the post-1980 period". She also says that "the tradition of children's book writers who know the child well; who understand concept of the basic criteria of children's literature; who make serious efforts on the philosophy of writing to children; and who open the way for his own authorship has started".

\section{Conclusions}

Turkish children's literature advances confidently to become a universal child literature by changing and evolving from its effective writers that bring together child's view, interests and wishes for the characteristics of Turkish language; and also, who follow scientific developments.

\section{Notes}

The research reported here derived from author's doctorate dissertation, which was conducted under the supervision of Prof. Dr. Osman Gündüz.

\section{REFERENCES}

[1] Ural, Y. (2014). Batı dünyasına Batı yazınına öykünen kitaplarla giremeyiz. Türk Dili Dergisi, CVII (756), $330-340$.

[2] Ergin, M. (1984). Dede Korkut Kitabı. İstanbul: Boğaziçi Yay mlar1.

[3] Türkdoğan, O. (1985). Dede Korkut destanında sosyal hareketler. Türk Kültürü Dergisi, (269) 571.

[4] Hacib, Y. H. (2004). Kutadgu Bilig. (4. Baskı). Ankara: Türkiye Diyanet Vakfı Yayınları.

[5] Yavuzer, H. (2011). Çocuk psikolojisi. (33. Basım). İstanbul: Remzi Kitapevi.

[6] Akyüz, Y. (1997). Türk eğitim tarihi. (6. Baskı). İstanbul: İstanbul Kültür Üniversitesi Yayınları.

[7] Suveydi, A. (2008) Hak sözün vesikaları. İstanbul: Hakikat Kitâbevi.

[8] Sarryüce, H. L. (2012) Türk çocuk ve gençlik edebiyat1 
ansiklopedisi. İstanbul: Nar Yayınları.

[9] Şimşek, T. (ed.). (2012). Kuramdan uygulamaya çocuk edebiyatı. Ankara: Grafiker Yaymları.

[10] Çılgın, A. S. (2007). Çocuk edebiyatı. İstanbul: Morpa Yayınlar1.

[11] Arslan, D. Z. (1997). Yalvaç Ural'ın hayatı ve eserleri üzerine bir çalışma. Yayımlanmamış yüksek lisans tezi. Gazi Üniversitesi Sosyal Bilimler Enstitüsü, Ankara.

[12] Enginün, İ. (1987). Çocuk edebiyatına toplu bir bakış. Çocuk Edebiyatı Y1llığ (1. Baskı) içinde. (186-194). Istanbul: Gökyüzü Yayınlar1.

[13] Okay, C. (2006). Eski Harfli Çocuk Dergileri. Türkiye Araştırmaları Literatür Dergisi, 4 (7), 512.

[14] Kul, N. (2009). Ahmet Midhat Efendi'nin roman ve hikâyelerinde eğitim aracı olarak edebiyat: kadın ve kız çocuklarının eğitimi. Yayımlanmamış doktora tezi. Marmara Üniversitesi Türkiyat Araştırmaları Enstitüsü, İstanbul.

[15] Acar, Ş. D. (2009). Eğitim tarihimizde bir üstadı Satı Bey’i tanımak. İstanbul: Akademik Kitaplar.

[16] Şimşek, T. (2006). Çocuk edebiyatı, Talât Sait Halman. (Ed.). Türk Edebiyat1 Tarihi, (c.4: 543-564). Ankara: Kültür ve Turizm Bakanlığı Yayınları.

[17] Argunşah, H. (1996). Ziya Gökalp'in Limni ve Malta mektuplarında aile, kadın ve çocuk eğitimi fikri. Erciyes Üniversitesi Sosyal Bilimler Enstitüsü Dergisi, 7, 243-267.

[18] Kıbrıs, İ. (2006) Çocuk edebiyatı. Ankara: Tek Ağaç Eylül Yayınları.

[19] Kanık, O. V. (2005). Nasrettin Hoca hikâyeleri. İstanbul: Yap1 Kredi Yayınlar1.

[20] Şirin, M. R. (2006b). Çocuğa adanmış konuşmalar. (2.Basım). İstanbul: İz Yayıncılık.

[21] Şirin, M. R. (1994a). Çocuk edebiyatı. İstanbul: Çocuk
Vakfı Yayınları.

[22] Kozanoğlu, A. Z. (2004). Kızıl Tuğ. İstanbul: Bilge Kültür Sanat Yayınları.

[23] Sağlık, Ş. (2005). Çocuk Romanları. Hece Çocuk Edebiyat Özel Sayıs1 (1. Bask1) içinde. (251). Ankara: Öncü Yayınlar1.

[24] Çocuk Edebiyatı Yıllığı, (1987). (1. Bask1) içinde. (353-356). İstanbul: Gökyüzü Yayınları.

[25] Gültekin, A. (2011). Çocuk ve gençlik edebiyatı yazıları. İstanbul: Erdem Yayınlar1.

[26] Yakut, G. Ü. (2006). Bekir Yıldız'ın hayatı ve romanları. Yayımlanmamış yüksek lisans tezi. Çanakkale Onsekiz Mart Üniversitesi Sosyal Bilimler Enstitüsü, Çanakkale.

[27] Yılmaz, O. (2013). Fatih Erdoğan'ın eserlerinin eğitsel değerler açısından incelenmesi. Doktora Tezi. Atatürk Üniversitesi Eğitim Bilimleri Enstitüsü, Erzurum.

[28] Koçer, G. (2011). İsmet Kür'ün hayat1, eğitimciliği ve Türk çocuk edebiyatına katkısı. Yayımlanmamış doktora tezi. Selçuk Üniversitesi Sosyal Bilimler Enstitüsü, Konya.

[29] Karagözoğlu, M. (2010). Mustafa Ruhi Şirin'in çocuk edebiyatına dair görüşleri. Yayımlanmamış yüksek lisans tezi. İstanbul Üniversitesi Sosyal Bilimler Enstitüsü, İstanbul.

[30] Semerci, B. (17 Kasım 2012). Çocuklar için kitap yazmak. Sabah Gazetesi. Erişim tarihi: 18.09.2014, www.sabah.com.

[31] Şirin, M. R. (1988). Mevlana İdris Zengin ile çocuklar için şiir üzerine. 1988 Çocuk Edebiyatı Yıllığı (1. Baskı) içinde. (208). İstanbul: Gökyüzü Yayınları.

[32] Şirin, M. R. (1987). 1986'da çocuk edebiyatı. Çocuk Edebiyatı Y1llığ1 (1. Bask1) içinde. (302). İstanbul: Gökyüzü Yayınlar1.

[33] Şirin, M. R. (2007c). Çocuk edebiyatına eleştirel bir bakış. Ankara: Kök Yayıncılık. 